\title{
Morphological and Physical Properties of Dehydrated Holocene Carbonate Limnic Deposits in Post-Bog Areas of NW Poland
}

\author{
Grzegorz Jarnuszewski ${ }^{*}$, Edward Meller ${ }^{1}$ \\ ${ }^{1}$ West Pomeranian University of Technology, Słowackiego 17 Str., 71-434 Szczecin, Poland \\ * Corresponding author's e-mail: grzegorz.jarnuszewski@zut.edu.pl
}

\begin{abstract}
Holocene limnic deposits characteristic of the average latitudes have partially outcropped as a result of young glacial sculpture aging. The change of the environment from limnic to telmatic and often the interference of a man associated with the regulation of water relations led to the emergence of limnic deposits that underwent the process of pedogenesis. In this work, 137 samples of carbonate deposits from 6 sites in NW Poland were analyzed in terms of their physical properties. Carbonate sediments were subject to determination of specific and bulk densities, total porosity and air porosity, current and capillary water capacity. On the basis of $\mathrm{CaCO}_{3}$ content, combustion loss, and non-lime mineral content, the studied sediments were classified into three groups: lacustrine chalk, calcareous gyttja, and clay-calcareous gyttja. Studies have shown that the sediments subject to pedogenesis in the top levels have characteristic morphological features in the form of cracks and numerous channels and iron fills in the form of spotted, streaked or marbled mosaic. The top levels of sediments, as a result of dehydration, clearly increase their bulk density. Properties of the lake chalk were formed mainly by the proportion of organic matter and $\mathrm{CaCO}_{3}$, while in the case of carbonate gyttja, the influence of mineral parts of the non-lime substances is also highlighted. In the top of carbonate sediments, there is a decrease in general and capillary porosity and an increase in the share of macropores.
\end{abstract}

Keywords: outcropped carbonate deposits, pedogenesis, lacustrine chalk, calcareous gyttja, clay-calcareous gyttja

\section{INTRODUCTION}

In the mid-latitudes, limnic deposits, the main constituent of which is $\mathrm{CaCO}_{3}$, are quite common [Verecchia 2007, Gierlowski-Kordesch 2010, Lemkowska 2013, Okupny et al. 2016]. As the age of young glacial sculpture and the accumulation of matter and energy in the reservoirs, the sediment shallowing occurred - especially in littoral - and the environmental conditions changed from limnic to swampy, and then to land. Changing of the humidity conditions caused a transformation in the physical, chemical and morphological characteristics of carbonate sediments, and the top levels were covered by the pedogenesis process [Freytet, Verecchia 2002, Verecchia 2007, Gierlowski-Kordesch 2010]. Hydromeliorations performed to acquire new areas for agricultural production have ag- gravated the changes in long-term dehydrated sediments [Lemkowska, Sowiński 2008, Kiryluk 2009, Lemkowska 2013, Glina et al. 2016]. Dehydrated Holocene carbonate deposits are characterized by the presence of marbled mosaic caused by the presence of iron oxides in the groundwater level fluctuation zone [Krzywonos 1993, Freytet, Verrecchia 2002, Alonso-Zarza, Wright 2009]. In addition, there are cracks, root canals (especially numerous in the top layers) and canals resulting from the activities of soil fauna [Uggla 1976, Krzywonos 1993]. These canals are often filled with the material derived from the organogenic levels that occur over carbonate sediments, which are eluted, illusive, and eroded [Piaścik, Gotkiewicz 2004, Kechavarzi et al. 2010]. In the hydrated state, carbonate deposits (lacustrine chalk and calcareous gyttja) occur in the form of a gel characterized by plasticity, low bulk density and 
high porosity as well as waterproofing properties [Wyrwicki 2003, Lemkowska 2013]. As a result of a long-term dehydration, the poly-ionic solution formed by hydrated carbonate deposits, is transformed - there is a skeletal shrinkage and often irreversible changes in colloids. The general porosity of carbonate sediments is reduced, calcite grains are aggregated, and cementation of the topsediment layers can occur, especially in the case when heavy equipment is used [Żurek-Pysz 1998, Freytet, Verrecchia 2002, Wyrwicki 2003, Lemkowska 2013].

The aim of the study was to determine the morphological and physical properties of carbonate limnic deposits covered by pedogenesis on the example of 6 objects in north-western Poland.

\section{STUDY SITE}

The study included a total of 6 sites where carbonate limnic deposits were found to be shallow under organogenic formations (Fig. 1). Object 1 was a big gyttja of about more than 100 ha area located near lake Miedwie, object 2 is an area of carbonate limnic deposits near lake Strzeszowskie, object 3 located near lake Sitno, object 4 situated at the lake Dubie, and object 5 localized near lake Drawsko Pomorskie. Objects 2, 3,
4 , and 5 are medium gyttjas with areas $10-100$ ha, while object 6 is a small gyttja with the area below 10 ha, situated near lake Sierakowo. Object 1 is a part of the Pleistocene ice-dammed lake consisting of five ice-dammed lake terraces that are the remains of a glacial-limnic reservoir, eventually formed in the phase of the Pomeranian ice sheet recession. The ice-dammed lake is surrounded by a moraine uphill with numerous drumlines and filled with stratified forms in the form of slimes, clays and sands. The accumulation valley itself is a subglacial gull formed by the action of a narrow glacier. From the Pre-Boreal, the accumulation of gyttja occurred within a reservoir called Pra-Miedwie [Pasierbski 1979, Karczewski et al. 2008]. Object 2 is located in a subglacial trough - Tywa river valley filled with sand and organic soil. The subglacial gutter crosses a morphologically diverse upland moraine composed of sand and clay [Jarnuszewski 2015]. Object 3 is located in the area of the lake plain covered with biogenic accumulation sediments formed from the ice-dammed lake plains, surrounded by a corrugated moraine rising built of sand, gravel and clay [Jarnuszewski 2015]. Object 4 is located in the area of a plain consisting of outwash sands with occurrences of bottom moraine hills. This area is situated in a subglacial gutter filled with alluvia carried by the flowing Drawa river. Object 5 is

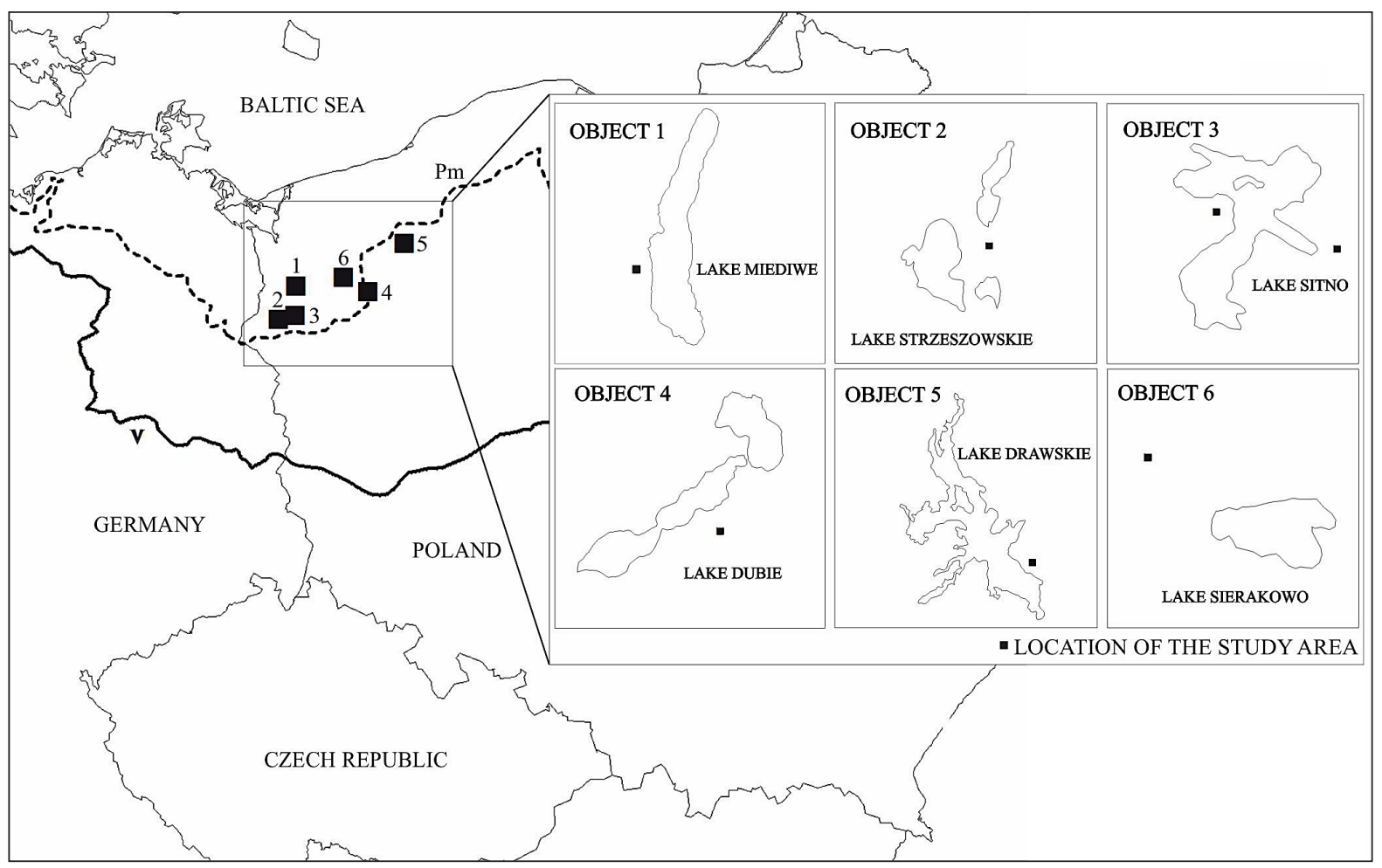

Figure 1. Location of the study objects including dehydrated limnic carbonate deposits near lakes in NW Poland 
located in the subglacial gutter of Drawsko Lake, which is part of a larger complex of so-called marginal gutter uncovered after the glaciation of the Leszno-Poznań phase filled with clay and patches of sand. Object 6 is located in a small terrain depression of the moraine upland made of sand and glacial tills [Lewandowski, Nita 2008, Jarnuszewski 2015]. The average annual temperature in the region ranges from $7.5^{\circ} \mathrm{C}$ to $8.5^{\circ} \mathrm{C}$ and the total precipitation ranges from $550 \mathrm{~mm}$ to 650 mm [Koźmiński et al. 2007].

\section{METHODS}

A total of 55 soil outcrops were made, from which 138 soil samples were collected for laboratory testing. The percentage of non-carbonate mineral fractions and $\mathrm{CaCO}_{3}$ was determined in the collected material. Limnic deposits were divided according to the percentage of organic matter, non-lime minerals, and calcium carbonate in line with the Markowski [1980] classification. The following sediment groups were distinguished: lacustrine chalk (carbonate gyttja with $\mathrm{CaCO}_{3}$ content above $80 \%$ ); calcareous gyttja (carbonate gyttja with $\mathrm{CaCO}_{3}$ content from $60 \%$ to $80 \%$ ); clay-calcareous gyttja (carbonate gyttja with $\mathrm{CaCO}_{3}$ content from $20 \%$ to $50 \%$ ). The samples were subjected to LOI determination by burning the material at $550^{\circ} \mathrm{C}$, the $\mathrm{CaCO}_{3}$ content by Scheibler's method, the proportion of noncarbonates fraction ( $\mathrm{Ncf}$ ) was calculated based on the reported results. The pycnometric method was used to determine the specific density. The weight-dry method using Kopecky cylinders was applied to determine bulk density, actual and capillary water capacity. On the basis of the obtained results of specific and bulk density, the total porosity was calculated. Total porosity and capillary water capacity were used to calculate the noncapillary porosity (air porosity). In order to characterize the lake chalk features, the samples taken from individual depths were assigned to three ranges: $0-50 \mathrm{~cm}, 50-100 \mathrm{~cm}$ and $>100 \mathrm{~cm}$ below the ground level. The results were analyzed statistically using Statistica 12.0 software.

\section{RESULTS AND DISCUSSION}

The studied carbonate deposits were found to be shallow under organic levels (peat, mursh - at different degree of decession) and black soils. The tested soils can be classified according to WRB [2015] to Sapric Histosols (Limnic), Sapric Histosols (Endolimnic), Drainic Histosols (Calcaric, Limnic), Murshic Histosols (Limnic), Umbric Gleysols (Hyperhumic), and Gleyic Phaeozems (Hyperhumic). The thickness of sediments was generally less than $2 \mathrm{~m}$ and their color corresponded, in the Munsell scale, to: $2.5 \mathrm{Y}, 5 \mathrm{Y}, 10 \mathrm{Y}$, 7.5YR, 10YR4-8/1-8. In the top layer of sediments, there was predominantly the lacustrine chalk, while in loamy-lime gyttja in the bottom. Limnic sediments were deposited on dusty and sandy soils, sometimes stratified with a large amount of the skeleton, sometimes on clay. The mineral layers that lay below the carbonate deposits, generally exhibit total marbling, and there is cementation of the grains with calcium compounds. In wet and fresh condition, they have plastic consistency. In the case of drying out, due to seasonal fluctuations in the groundwater level at layers located in the top of the sediments, they assume hard plastic or solid form. In the analyzed limestone, there are mollusc residues (Mollusca) in the form of shells, which are characteristic of littoral zone deposits [Kelts and Ksu 1978, Krzywonos 1993, Wyrwicki 2001, Schnurrenberger et al. 2003, Verrecchia 2007]. The characteristic feature of the analyzed soil profiles was the presence of marbled mosaic (Fig. 2) caused by the iron oxides in the fluctuation zone of the groundwater level [Krzywonos 1993, Freytet, Verrecchia 2002, Alonso-Zarza, Wright 2009]. Particularly high amount of iron-manganese precipitates, mainly in the oxidized form, was observed in the top layers of sediments deposited directly below the organogenic levels subjected to murshing processes [Piaścik, Bieniek 2001, Grzywna 2014]. In this case, the murshing process is an important source of iron and manganese, which are subjected to illuviation with drainage water and can precipitate in the top layers of sediments. In the profiles of limnic sediments, especially in the top layers, cracks and root canals, as well as canals being the result of the soil fauna activity, were found (Fig. 1). As indicated by Kelts and Ksu [1978], Freytet and Verrecchia [2002], Schnurrenberger et al. [2003], Alonso-Zarza and Wright [2009], Gierlowski-Kordesch [2010], these features are characteristic for littoral deposits fraction subject to soil-formation processes and converted into bog fractions, so-called palustrine limestones. The canals and cracks occurring in the top layers of car- 


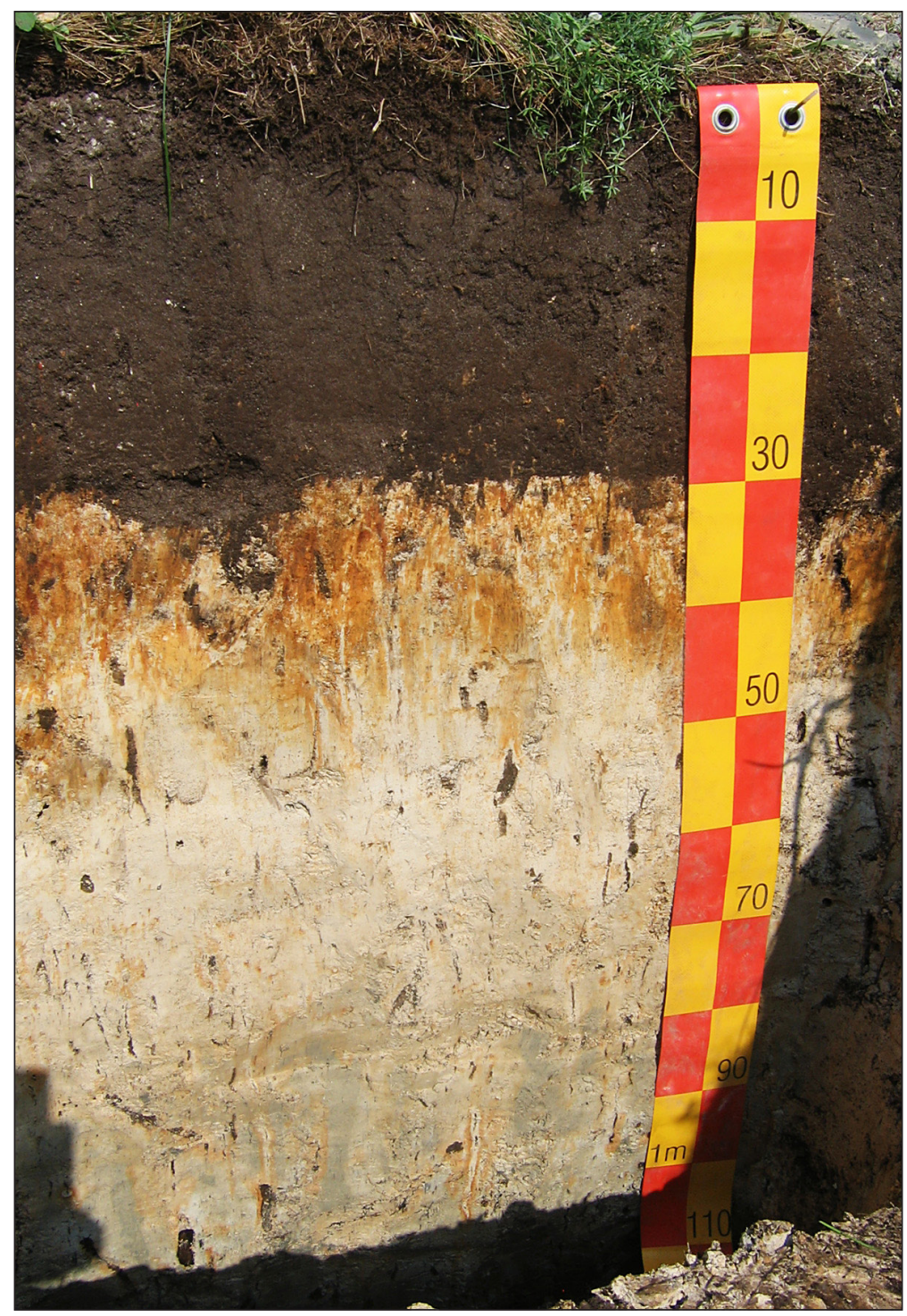

Figure 2. Morphological characteristics of dehydrated limnic carbonate sediments exposed in the soil profile

bonate sediments are often filled with organogenic material over sediments, which are subject to eluviation, illuviation, and vertilization [Piaścik, Gotkiewicz 2004, Kechavarzi et al. 2010].

In terms of the physical properties, lacustrine chalk and calcareous gyttja deposits exhibited similar bulk and specific density as well as general porosity and water capacities (current and capillary) (Table 1). Against this background, the clay-calcareous gyttja deposits were characterized by significantly higher bulk density $(1.453$ $\left.\mathrm{Mg} \cdot \mathrm{m}^{3}\right)$ and lower total porosity $\left(0.450 \mathrm{~m} \cdot \mathrm{m}^{3}\right)$, and hence both water capacities (Table 1). The clay-calcareous gyttja deposits were characterized by the highest ratio of air porosity to total porosity $(10.9 \%)$ in comparison to calcareous gyttja $(8.26 \%)$ and lacustrine chalk (6.64\%). These differences were caused by the composition of ingredients forming various types of formations. Lacustrine chalk and calcareous gyttja are mainly composed of fine crystalline calcite, which when moistened, forms a kind of a gel [Kelts, Ksu 1978, Żurek-Pysz 1992, Wyrwicki 2001, Gierlowski-Kordesch 2010, Lemkowska 2013]. Ground skeleton components (mainly fine-crystalline calcite) are in a colloidal poly-ionic solution, which is an integral constituent binding the remaining components [Wyrwicki 2001]. In the case of clay-calcareous gyttja, the main component is allogeneic clay minerals, dust and sand derived from the physical and chemical erosion of the catchment areas and transported by water or wind [Kelts and Ksu 1978, Schnurrenberger et al. 2003, Gierlowski-Kordesch 2010]. The claycalcareous gyttja was found most commonly in the carbonate deposit, which may indicate the 
Table 1. Selected properties of dehydrated carbonate limnic deposits in NW Poland according to type

\begin{tabular}{|c|c|c|c|c|c|c|c|c|c|c|}
\hline \multirow[t]{2}{*}{$\begin{array}{l}\text { Kind of } \\
\text { gyttja }\end{array}$} & \multirow[t]{2}{*}{ Value } & LOI & $\mathrm{CaCO}_{3}$ & Ncf & $\begin{array}{l}\text { Specific } \\
\text { density }\end{array}$ & $\begin{array}{l}\text { Bulk } \\
\text { density }\end{array}$ & $\begin{array}{c}\text { Tota } \\
\text { porosity }\end{array}$ & $\begin{array}{c}\text { Air } \\
\text { porosity }\end{array}$ & $\begin{array}{c}\text { Actual } \\
\text { water } \\
\text { capacity }\end{array}$ & $\begin{array}{c}\text { Capilary water } \\
\text { capacity }\end{array}$ \\
\hline & & \multicolumn{3}{|c|}{$\%$} & \multicolumn{3}{|c|}{$\mathrm{Mg} \cdot \mathrm{m}^{-3}$} & \multicolumn{3}{|c|}{$\mathrm{m}^{3} \cdot \mathrm{m}^{-3}$} \\
\hline \multirow{2}{*}{$\begin{array}{c}\text { Lacustrine } \\
\text { chalk } \\
n=114\end{array}$} & Mean & 2.77 & 90.71 & 6.53 & 2.633 & 1.050 & 0.602 & 0.040 & 0.509 & 0.562 \\
\hline & SD & 2.09 & 5.45 & 4.98 & 0.040 & 0.212 & 0.078 & 0.020 & 0.110 & 0.081 \\
\hline \multirow{2}{*}{$\begin{array}{c}\text { Calcareous } \\
\text { gyttja } \\
n=16\end{array}$} & Mean & 5.25 & 68.09 & 26.65 & 2.637 & 1.043 & 0.605 & 0.050 & 0.487 & 0.556 \\
\hline & SD & 5.73 & 9.77 & 11.16 & 0.043 & 0.211 & 0.077 & 0.024 & 0.130 & 0.074 \\
\hline \multirow{2}{*}{$\begin{array}{c}\text { Clay- } \\
\text { calcareous } \\
\text { gyttja } \\
n=7\end{array}$} & Mean & 4.03 & 36.23 & 59.74 & 2.643 & 1.453 & 0.450 & 0.049 & 0.303 & 0.402 \\
\hline & SD & 7.68 & 9.00 & 13.25 & 0.025 & 0.092 & 0.034 & 0.018 & 0.126 & 0.042 \\
\hline
\end{tabular}

genesis of the Late Pleistocene (Alleröd and Young Dryas), when the best conditions for depositing such materials occurred [Wyrwicki 2003, Błaszkiewicz 2007]. The physical properties of lake chalk were significantly dependent primarily on the percentage of LOI and $\mathrm{CaCO}_{3}$ (Table 2). Although the share of organic matter in the lacustrine chalk was low (on average $2.77 \%$ ), it significantly affected the density decrease and the porosity increase and the number of mesopores. The increase in the dominant component, i.e. $\mathrm{CaCO}_{3}$, in the lacustrine chalk affected the reduction in porosity (significant correlation $r=-0.30$ ) and capillary water capacity $(r=-0.30)$ to a lesser extent than the LOI, and increased chalk specific density (Table 2). Calcareous gyttjas contained more than $20.1 \% \mathrm{Ncf}$ and $2.5 \%$ organic matter in comparison to the lacustrine chalk. For this limnic deposit, a significant effect of the increasing Ncf share on the bulk density $(r=0.51)$, general porosity $(\mathrm{r}=-0.52)$, and the number of capillaries $(r=-0.57)$, was observed. On the other hand, the increase in the amount of organic matter in the calcareous gyttjas significantly influenced on the specific density reduction $(\mathrm{r}=-0.86)$ and increase in the general porosity $(\mathrm{r}=0.66)$, while the $\mathrm{CaCO}_{3}$ content correlated with the number of capillaries $(r=0.52)$. In the case of clay-calcareous gyttja, no significant relationship was observed between the physical properties and the proportion of individual components.

The analyzed carbonate sediments exhibited similar bulk density and total porosity as well as significantly lower air porosity and higher number of mesopores to the emerged carbonate sediments described by Krzywonos [993]. In contrast, in comparison with the sediments, the deposits of the lacustrine chalk of Wigry Lake were characterized by significantly higher bulk density (about $1.2-1.6 \mathrm{Mg} \cdot \mathrm{m}^{3}$ ) caused by the compaction due to the pressure of the water column [Rutkowski et al. 2007, Aleksander-Kwaterczak, Kostka 2011].

Carbonate sediments have been found to vary in their physical properties depending on the depth of the sediment. The top layers of sediments up to a depth of $50 \mathrm{~cm}$ below the ground level exhibited significantly higher specific and bulk density as well as lower total porosity. Along with the drying of the upper layers of sediments, the increases of air porosity and the decrease of capillary and

Table 2. Correlation between the share of basic components of carbonate sediments and their physical properties

\begin{tabular}{|c|c|c|c|c|c|c|c|}
\hline $\begin{array}{l}\text { Kind of } \\
\text { gyttja }\end{array}$ & Variable & $\begin{array}{l}\text { Specific } \\
\text { density }\end{array}$ & Bulk density & Total porosity & Air porosity & $\begin{array}{c}\text { Actual } \\
\text { water capacity }\end{array}$ & $\begin{array}{c}\text { Capilary } \\
\text { water capacity }\end{array}$ \\
\hline \multirow{3}{*}{$\begin{array}{l}\text { Lacustrine } \\
\text { chalk } \\
n=114\end{array}$} & LOI & $-0.63^{*}$ & $-0.69^{*}$ & $0.68^{*}$ & -0.04 & $0.55^{\star}$ & $0.67^{*}$ \\
\hline & $\mathrm{CaCO}_{3}$ & $0.38^{*}$ & $0.32^{*}$ & $-0.30^{*}$ & 0.02 & $-0.24^{*}$ & $-0.30^{*}$ \\
\hline & $\mathrm{Ncf}^{\star *}$ & $-0.18^{*}$ & -0.10 & 0.09 & -0.01 & 0.07 & 0.09 \\
\hline \multirow{3}{*}{$\begin{array}{c}\text { Calcareous } \\
\text { gyttja } \\
n=16\end{array}$} & LOI & $-0.86^{*}$ & -0.49 & 0.44 & $0.66^{*}$ & -0.16 & 0.24 \\
\hline & $\mathrm{CaCO}_{3}$ & 0.05 & -0.41 & 0.43 & -0.24 & $0.51^{*}$ & $0.52^{*}$ \\
\hline & $\mathrm{Ncf}^{\star *}$ & 0.13 & $0.51^{*}$ & $-0.52^{*}$ & 0.10 & -0.48 & $-0.57^{*}$ \\
\hline \multirow{3}{*}{$\begin{array}{c}\text { Clay- } \\
\text { calcareous } \\
\text { gyttja } \\
n=7\end{array}$} & LOI & -0.32 & 0.02 & -0.08 & -0.12 & 0.22 & -0.01 \\
\hline & $\mathrm{CaCO}_{3}$ & -0.65 & -0.20 & 0.10 & -0.58 & 0.64 & 0.30 \\
\hline & $N c f^{\star *}$ & 0.64 & 0.19 & -0.09 & 0.58 & -0.64 & -0.30 \\
\hline
\end{tabular}

$*$ Correlations relevant for significance level $\mathrm{p}<0.05$. 

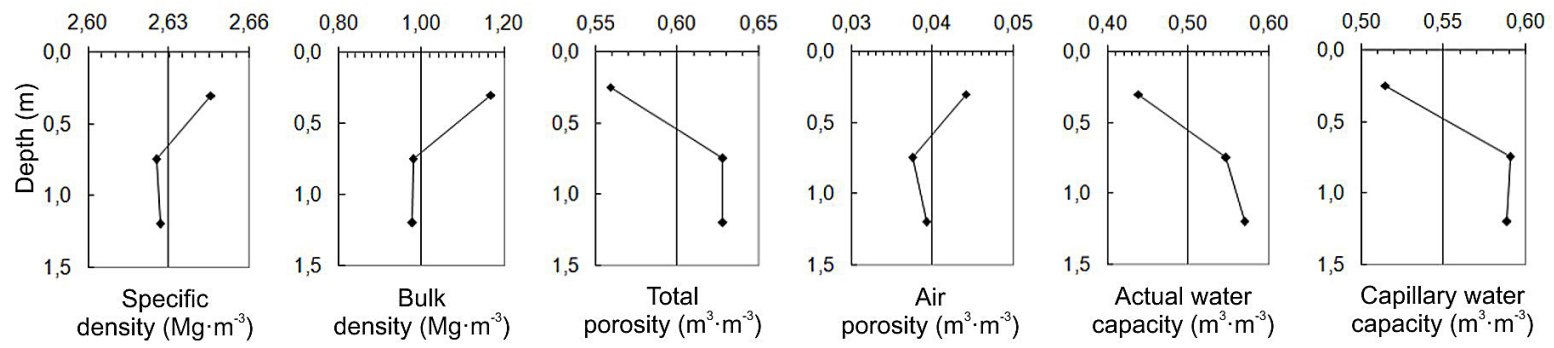

Figure 3. Vertical distribution of physical properties in dehydrated limnic carbonate deposits from NW Poland

actual water capacity were also observed (Fig. 3). The drying of the top layers leads to a shrinkage of the lake chalk frame and irreversible changes in colloids [Lemkowska 2013]. As a result of prolonged dehydration, the total porosity of the carbonate sediments is reduced, calcite grains are aggregated, and cementation of the top layers can occur [Żurek-Pysz 1998, Freytet, Verrecchia 2002, Lemkowska 2013]. The $\mathrm{CaCO}_{3}$ content in the sediments clearly increased from the lower layers to the bed top. Uneven amounts of individual components depending on the depth of sediment deposition can be explained by the change in sediment formation conditions. In deeper layers, the contribution of phyto and zooclasts derived from the organisms involved in the formation of sediments, is clearer, which translates to an increase in the amount of organic matter [Wyrwicki 2001, Lemkowska 2013]. As the reservoirs became shallower, the role of physical processes in the formation of sediments related to rapid heating of shallow waters and a reduction in $\mathrm{CO}_{2}$ solubility, increased [Jones and Browser 1978, Verrecchia 2007, Gierlowski-Kordesch 2010].

\section{CONCLUSION}

The emerged Holocene limnic-origin carbonated sediments are subject to the processes of pedogenesis that leads to the changes in the morphology and physical properties of sediments. The morphological changes occurring in the top layers of sediments undergoing the soil-forming processes involve the formation of cracks, numerous root canals, and canals resulting from the activity of soil fauna. The fluctuation of the groundwater level and illuviation of iron and manganese from the organogenic levels under the moorshing leads to the formation of iron fusions in the form of spotting, staining or marbling mosaic. Dehydrated levels are dried up in the top layers resulting in the shrinkage of the skeleton and changes in colloids leading to a marked increase in bulk density. The compaction of sediments resulting from a long-term dehydration of carbonate limnic top sediments causes a decrease in general and capillary porosity and, at the same time, an increase in the share of macropores. In the case of the carbonate limnic deposits, the physical properties are determined by the proportions of main components. In the lacustrine chalk and calcareous gyttja, significant interactions were observed between the increase in the proportion of organic matter and the decrease in specific density. In the lake chalk, the share of organic matter also significantly decreased the bulk density and had a positive effect on the overall porosity and number of capillaries. In the calcareous gyttja, the amount of capillaries was dependent on the proportion of $\mathrm{CaCO}_{3}$, while the increase in the Ncf share contributed to an increase in the bulk density and decrease in the general and capillary porosity.

\section{REFERENCES}

1. Aleksander-Kwaterczak U., Kostka A. 2011. Lead in the environment of Lake Wigry (NE Poland). Limnological Review, 11(2): 59-68.

2. Alonso_Zarza A.M., Wrigt V.P. 2010. Palustrine carbonates. In: Alonso-Zarza A.M., Tanner L.H. (eds): Carbonates in Continental Settings: Facies, Environments, and Processes. Elsevier, Developments in Sedimentology, 61: 103-132.

3. Błaszkiewicz M. 2007. Origin and evolution of lake basins on early post-glacial landscape - selected issue. Studia Limnologica et Telmatologica 1: 5-16 (in Polish)

4. Freytet P., Verrecchia E. 2002. Lacustrine and palustrine carbonate petrography: an overview. Journal of Paleolimnology, 27: 221-237.

5. Gierlowski-Kordesch E.H. 2010. Lacustrine Carbonates. In: Alonso-Zarza A.M., Tanner L.H. (eds): Carbonates in Continental Settings: Facies, Environments, and Processes. Elsevier, Developments in Sedimentology, 61: 1-101. 
6. Glina B., Gajewski P., Kaczmarek Z., Rybczyński P. 2016. Current state of peatland soils as an effect of long-term drainage - preliminary results of peatland ecosystems investigation in the Grójecka Valley (central Poland). Soil Science Annual, 67(1): 3-9.

7. Grzywna A. 2014. Evaluation of nutrient abundance in peat-muck soils of the Tyśmienica River Basin. Water-Envirinment-Rural Areas, 14(1): 1926. (In Polish)

8. IUSS Working Group WRB. 2015. World reference base for soil resources 2014. International soil classification system for naming soils and creating legends for soil maps. Update 2015. World Soil Resources Report 106, Food and Agriculture Organization of the United Nations, Rome: 188 pp.

9. Jarnuszewski G. 2015. Chemical properties of organic soils developed from lacustrine chalk near the lakes Strzeszowskie, Sitno, and Sierakowo (Western Pomerania, north Poland). Soil Science Annual, 66(4): 168-179. (In Polish)

10. Jones B.F., Bowser C.J. 1978. The mineralogy and related chemistry of lake sediments. In: Lerman A. (ed): Lakes Chemistry Geology Physics. Berlin, Heidelberg, New York, Springer-Verlag: 179-235.

11. Karczewski A., Dmowska A., Stach A., Gudowicz J., Beszterda I., Łukaszczyk T., Smyk R., Uflik A. 2008. Geomorphology of the Myślibórz Lakeland and Szczecin Lowland. Numerical Geomorphological Map. AMU Institute of Paleogeography and Geoecology.

12. Kechavarzi C., Dawson Q., Leeds-Harrison P.B. 2010. Physical properties of low-lying agricultural peat soils in England. Geoderma, 154: 196-202.

13. Kelts K., Hsü K.J. 1978. Freshwater Carbonate Sedimentation. In: Lerman A. (ed): Lakes Chemistry Geology Physics. Berlin, Heidelberg, New York, Springer-Verlag: 295-323.

14. Kiryluk A. 2009. Drying process in podt-bog meadow habitats. Water-Environment-Rural Areas, 9(4): 59-69. (In Polish)

15. Koźmiński C., Michalska B., Czarnecka M. 2007. The climate of the West Pomeranian voivodeship. Akademia Rolnicza w Szczecinie, Uniwersytet Szczeciński: 1-147. (In Polish)

16. Krzywonos K., 1993. Organogenic Carbonaceous Soils on Lacustrine Chalk. Characteristics and Classification Wiadomości IMUZ, 17(3): 37-55. (In Polish)

17. Lemkowska B. 2013. "Quaternary rendzinas" in the Systematics of Polish Soil. Soil Science Annual, 64(4): 135-139. (In Polish)

18. Lemkowska B., Sowiński P. 2008. Evolution of "post lake rendzinas" in the landscape of the Mazurian Lakeland. Soil Science Annual, 59(1):
134-140. (In Polish)

19. Lewandowski J., Nita M. 2008. Evolution of the hydrographic system and vegetation in the drainage basin of the upper Piława and the upper Drawa Rivers (Pomorze Środkowe). Polish Geological Review, 56(5): 380-390. (In Polish)

20. Markowski S. 1980. Structure and properties of peatlands' bottom lake sediments of frequent occurrence in West Pomerania region as a basis for their identification and classification. In: Post conference materials Lake marl and gyttja, Gorzów Wielkopolski-Zielona Góra: 45-55. (In Polish)

21. Okupny D., Rzepecki S., Borówka R. K., Forysiak J., Twardy J., Fortuniak A., Tomkowiak J. 2016. Factors influencing temporal changes in chemical composition of biogenic deposits in the middle Tążyna Ricer Valley (Kuyavian Lakeland, central Poland). Geologos, 22(2): 121-136.

22. Pasierbski M. 1979. Remarks on the Genesis of Subglacial Channels in Northen Poland. Eiszeitalter u. Gegenwart, 29: 189-200.

23. Piaścik H., Bieniek B. 2001. Changes in iron forms concentration as the result of the mucking process in different dehydration conditions. Soil Science Annual, 59: 119-125. (In Polish)

24. Piaścik H., Gotkiewicz J. 2004. Transformation of dewatered peat soils as the cause of their. Soil Science Annual, 55(2): 331-338. (In Polish)

25. Rutkowski J., Król K., Szczepańska J. 2007. Lithology of the profundal sediments in Słupiańska Bay (Wigry Lake, NE Poland)-introduction to interdisciplinary study. Geochronometria, 27: 47-52.

26. Schnurrenberger D., Russel J., Kelts K. 2003. Classification of lacustrine sediments based on sedimentary components. Journal of Paleolimnology, 29: $141-154$.

27. Uggla H. 1976. Rendzinas in the Mazurian Lakeland. Soil Science Annual, 28(2): 113-125. (In Polish)

28. Verrecchia E. 2007. Lacustrine and palustrine geochemical sediments. In: Nash D.J., McLaren S.J. (eds): Geochemical Sediments and Landscapes. Oxford, UK, Blackwell Publishing Ltd: 298-329.

29. Wyrwicki R. 2001. Holocene carbonate sediments: properties and chemistry of gel, composition of liquid and solid components. Polish Geological Review, 49(6): 525-532. (In Polish)

30. Wyrwicki R. 2003. Has lacustrine chalk originated in freshwater environment? Przegląd Geologiczny, 51(6): 483-488. (In Polish).

31. Żurek-Pysz U. 1992. Strength and deformability of an organic-calcareous lacustrine deposit (gyttja) in relation to its water content and colloid content. Bulletin of the International Association of engineering geology, 45: 117-126. 